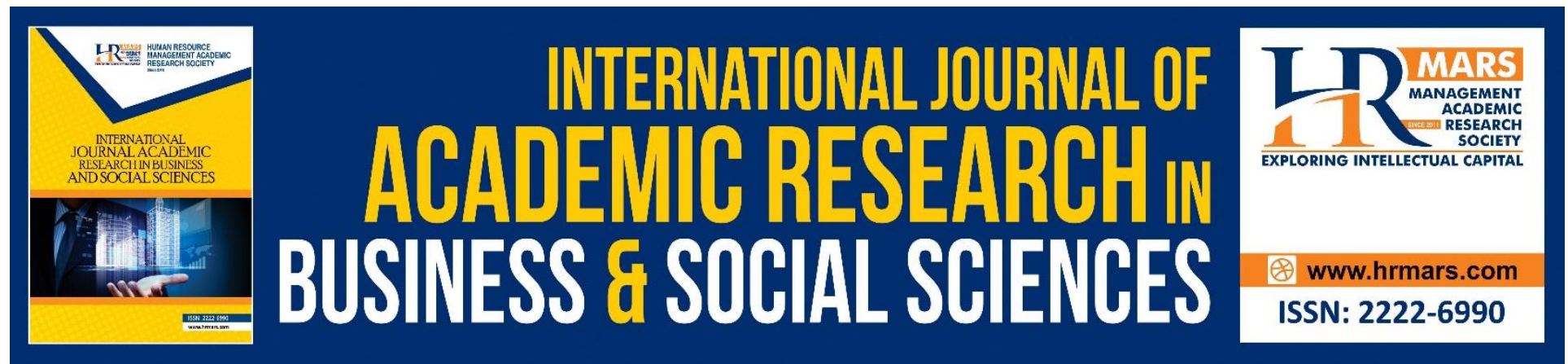

\title{
The Effect of using Interactive Multimedia Courseware with Pedagogical Agent in Learning Nutrition towards Higher Order Thinking Skills
}

Norsaliza Sabu

To Link this Article: http://dx.doi.org/10.6007/IJARBSS/v8-i2/3971

DOI: $10.6007 /$ IJARBSS/v8-i2/3971

Received: 20 January 2018, Revised: 18 February 2018, Accepted: 25 February 2018

Published Online: 06 March 2018

In-Text Citation: (Sabu, 2018)

To Cite this Article: Sabu, N. (2018). The Effect of using Interactive Multimedia Courseware with Pedagogical Agent in Learning Nutrition towards Higher Order Thinking Skills. International Journal of Academic Research in Business and Social Sciences, 8(2), 612-623.

Copyright: (C) 2018 The Author(s)

Published by Human Resource Management Academic Research Society (www.hrmars.com)

This article is published under the Creative Commons Attribution (CC BY 4.0) license. Anyone may reproduce, distribute, translate and create derivative works of this article (for both commercial and non-commercial purposes), subject to full attribution to the original publication and authors. The full terms of this license may be seen

at: $\underline{\text { http://creativecommons.org/licences/by/4.0/legalcode }}$

\begin{tabular}{|c|c|}
\hline \multicolumn{2}{|c|}{ Vol. 8, No.2, February 2018, Pg. 612 - 623} \\
\hline http://hrmars.com/index.php/pages/detail/IJARBSS & JOURNAL HOMEPAGE \\
\hline
\end{tabular}

Full Terms \& Conditions of access and use can be found at http://hrmars.com/index.php/pages/detail/publication-ethics 


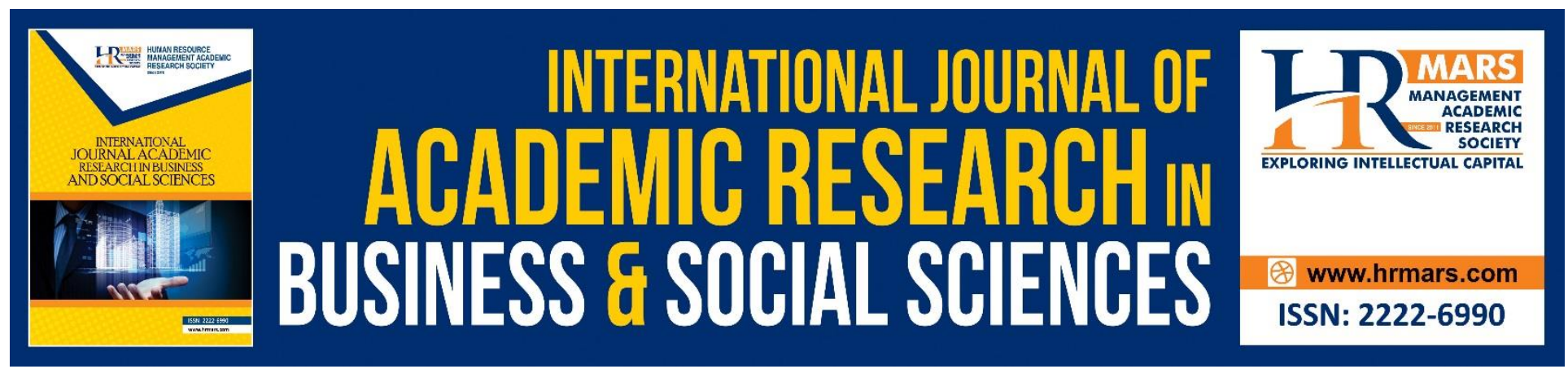

\title{
The Effect of using Interactive Multimedia Courseware with Pedagogical Agent in Learning Nutrition towards Higher Order Thinking Skills
}

\author{
Norsaliza Sabu \\ Faculty of Education and Human Development, Sultan Idris Education University, 35900 Perak, \\ Malaysia \\ Email:norsalizas@gmail.com
}

\begin{abstract}
This study aims to design and develop a courseware named Nutri-Score with pedagogical agent for the topic of Nutrition in Biology form four. This quasi-experimental design study involved 181 students from two secondary schools in Kedah and Penang respectively. 90 respondents from the treatment group studied Nutrition through Nutri-Score while the other 91 respondents from the control group studied Nutrition cooperatively. Then the learning effect by using the two teaching strategies were tested on four dependent variables namely higher order thinking skills and their components which are classifying skill as well as comparing and contrasting skill. The four dependent variables were set according to the New Taxonomy from Marzano Model. The findings were analyzed inferentially by using the Multivariate Analysis of Covariance (MANCOVA) Test. The pre-test result was used as the covariate. The quantitative analysis showed that the use of Nutri-Score has helped to improve the higher order thinking skills, classifying skill as well as the comparing and contrasting skill in pupils significantly. This study contributes to the method of designing and developing a teaching courseware to enhance higher order thinking skills among secondary school Biology students. The positive results produced contribute positive implications to the models and theories which were integrated in the design and development of the courseware.
\end{abstract}

Keywords: Higher Order Thinking Skills, Classifying Skill, Comparing and Contrasting Skill, Interactive Courseware, Marzano Model, Pedagogical Agent, Nutrition

\section{Introduction}

Biology is one of the elective science subjects that is being taught at the secondary level of Malaysian schools in form four. Form Four Biology Curriculum is divided into four themes which are introducing Biology, investigating the cell as a basic unit of living things, investigating the physiology of living things and investigating the relationship between living things and the environment (Ministry of Education Malaysia, 2005). Nutrition is the sixth topic and it is in the 
theme of investigating the physiology of living things. Based on the theme, it shows that Nutrition contains difficult Science concepts because involving abstract and microscopic physiological processes. According to the curriculum, Nutrition is divided into two parts which are Nutrition for Animals and Nutrition for Plants.

One of the objectives to be achieved in Biology teaching at secondary schools is to improve the students' higher order thinking skills through critical and creative thinking skills. Critical thinking skills include attributing, comparing and contrasting, grouping and classifying, sequencing, prioritizing, analyzing, detecting bias, evaluating and making conclusions. In Nutrition, critical thinking skills are focused on classifying skill which is suggested in subtopics Understanding Types of Nutrition whereas comparing and contrasting skill is suggested in the subtopics of Analyzing Food Digestion. Hence, the auxiliary materials for teaching Nutrition that should be provided to or by the teachers must be able to improve the classifying skill as well as the comparing and contrasting skill among the students.

According to King, Goodson and Rohani (1998), the teaching strategies for developing higher order thinking skills should be student-centered. The strategies that they suggested are group activities, student discussions, peer guidance, cooperative learning and computer-assisted learning. In the Form Four Biology Curriculum, several examples of teaching strategies to enhance higher order thinking skills in Nutrition are recommended to the teachers by the Ministry of Education Malaysia. For example, the use of computerized animation to teach the subtopic of Absorption of Digested Food in the small intestine into the blood. Another strategy is to incorporate cooperative learning in small groups of students to discuss the subtopics of Balanced Diet, Malnutrition, Evaluating Eating Habits and Realizing the Importance of a Healthy Digestive System.

\section{Background of the Study}

Problem which often faced by the students studying Biology are weak in mastering the basic concepts of Biology. Among Biology topics that contain the difficult concepts of Science for students to master in is Nutrition. This problem is proven by the findings of the previous study by the researcher on 196 Biology form four students who acknowledged nine out of ten subtopics in Nutrition as difficult while one subtopic is very difficult. The weakness to master in the Science concepts was also exposed by the Malaysian Examinations Syndicate (2010, 2013 \& 2014) on the candidates from low performance group in the Malaysian Certificate of Education (Sijil Pelajaran Malaysia) examination. If this problem is not resolved, the increase in the number of high cognitive level items to the Biology paper in the Malaysian Certificate of Education (Sijil Pelajaran Malaysia) examination will further complicate the situation. While deep understanding of a concept is a prerequisite for enhancing higher order thinking skills among students (Thomas \& Thorne, 2009).

The Malaysian Examinations Syndicate (2013 \& 2014) has reported that candidates for the Malaysian Certificate of Education examination from the middle performance group failed to give good respond to the items of comparing and contrasting. If the candidates from the middle performance group are having difficulty, of course the candidates from the low performance 
group are facing the same problem in comparing and contrasting. So in this study, the researcher conducted a research on higher order thinking skills by focusing on the comparing and contrasting skill. In addition, the researcher also choose the skill of classifying as another dependent variable. Classifying skill and comparing and contrasting skill are among the higher order thinking skills contained in the third level of New Taxonomy of Marzano Model, which is the level of analysis. The New Taxonomy contains six levels in a single hierarchy where the order does not reflect the complexity of each level. The comparison between classifying skill and comparing and contrasting skill in the New Taxonomy and the Bloom Taxonomy is shown in Table 1.

Table 1 Mental Operations in Level 3 of New Taxonomy

\begin{tabular}{lll}
\hline Process & Explanation & Comparison with Bloom Taxonomy \\
\hline Classifying & $\begin{array}{l}\text { Students identifying superordinate } \\
\text { and subordinate categories related } \\
\text { to the knowledge. }\end{array}$ & $\begin{array}{l}\text { It identifies a set of abstract } \\
\text { relationships at level } 5 \text { which is } \\
\text { synthesis. }\end{array}$ \\
$\begin{array}{l}\text { Comparing and } \\
\text { contrasting }\end{array}$ & $\begin{array}{l}\text { Students identify important It resembles the analysis of } \\
\text { similarities and differences relationships in level } 4 \text { which is } \\
\text { between knowledge components. analysis. }\end{array}$
\end{tabular}

Besides, teachers in Malaysia are facing challenges to implement teaching based on higher order thinking skills despite the fact that the policy was started since 2013. In addition to having adequate knowledge and appropriate attitudes, they also need to be skilled in certain pedagogy techniques to be capable to enhance higher order thinking skills among students (Barak \& Shakhman, 2008; Rajendran, 2010). Internal courses and exposure to questioning techniques are insufficient. The task load and time constraints, restraining teachers from exploring the appropriate pedagogy techniques even though to prepare teaching tools by themselves. In fact, it is easy for the teachers to use supplied modules and materials as teaching aids based on higher order thinking skills because teachers nowadays are burdened with lots of daily responsibilities (Rajendran, 2010). Hence, teaching aids like a multimedia courseware which integrated with teaching strategies of higher order thinking skills will really help the teachers.

The Ministry of Education Malaysia has supplied multimedia courseware for Mathematics, Science, Physics, Chemistry and Biology subjects to the secondary schools. Unfortunately, MDEC (2008) has reported that the percentage of usage of the multimedia courseware by teachers is very low which is less than $10 \%$. Teachers claim that the courseware do not allow the students to understand the concepts, students cannot access the courseware on their own, the contents are less relevant to the actual experience of the students, do not following the correct steps of teaching strategies and often down the computer operation. The students criticize the courseware as boring, reducing bilateral interactions with teachers, the graphics are uninteresting, the examples are unclear, do not help them in understanding, do not give them the opportunity for self-access and their teachers are seldom using the courseware as they have to pursue time to go to another classes. 
Hence, the researcher has designed and developed a stand-alone multimedia courseware that is Nutri-Score for students to use during the study of Nutrition. The content in the Nutri-Score only focuses on Nutrition for Animals. The researcher cares about all the comments from the teachers and students to minimize the weaknesses in the Nutri-Score. The researcher integrates Cognitive Theory of Multimedia Learning (CTML), Cognitive Theory of Multimedia Learning with Animated Pedagogical Agent (CTMLAPA) and Cognitive Load Theory to design and develop the Nutri-Score. A pedagogical agent with a cartoon character named Madam Saliza was added according to CTMLAPA. The pedagogical agent plays four key roles, which are as (i) an expert who provides information, (ii) a mentor who provides advice, (iii) a motivator and (iv) a friend who provides assistance (Kim \& Baylor, 2008). The content in the Nutri-Score is presented step by step according to the nine steps in the Gagne's Events of Instruction. The teaching strategy used was based on the 5E Model which support the Constructivism Theory. Figure 1 shows the flowchart of the Nutri-Score design process.

\section{Diagram 1 The flowchart of the Nutri-Score design process}

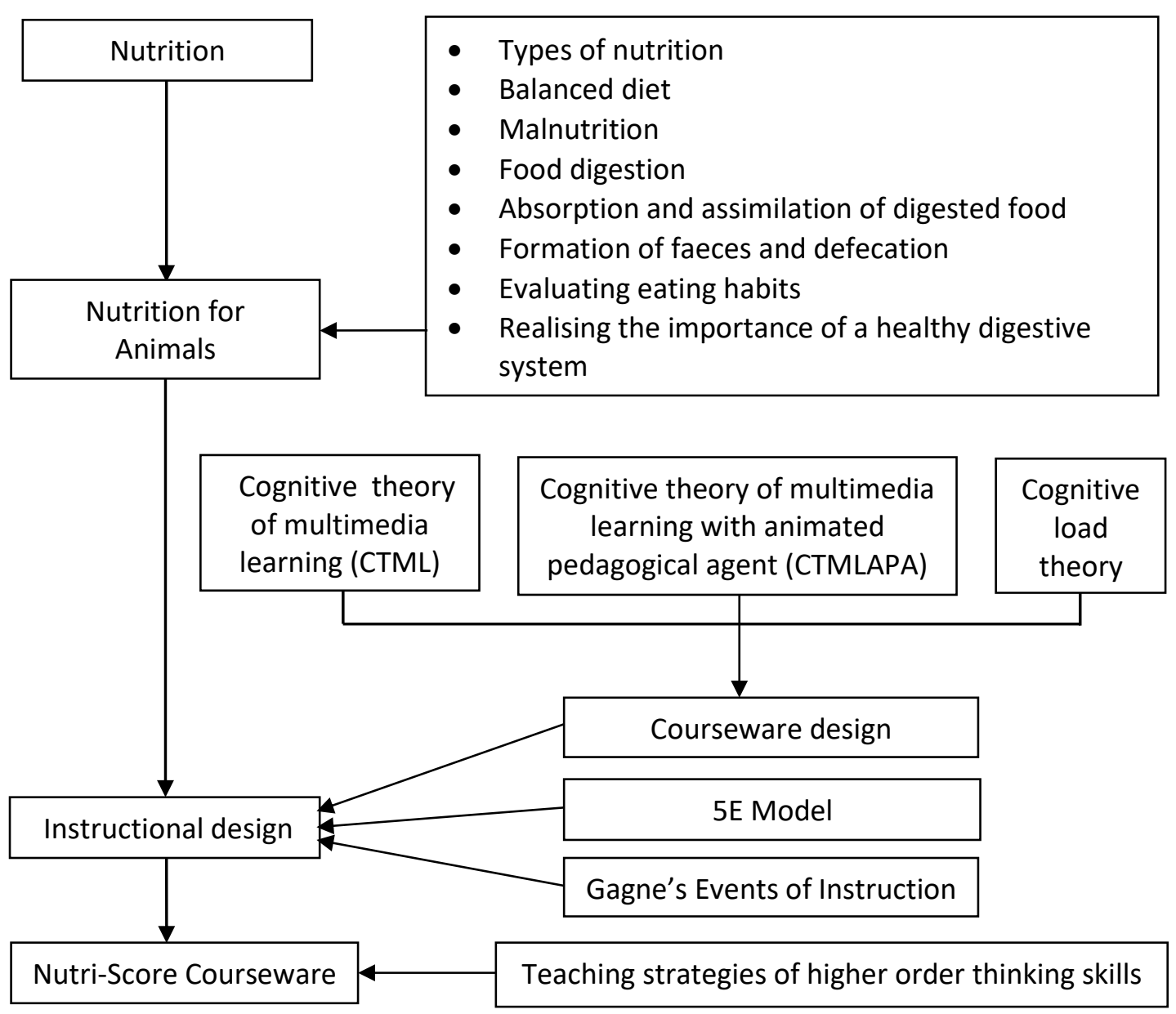

\section{Research Questions}

There are 3 questions in this study 
(a) Is there a difference in higher order thinking skills between the control group and the treatment group?

(b) Is there a difference in classifying skill between the control group and the treatment group?

(c) Is there a difference in comparing and contrasting skill between the control group and the treatment group?

\section{Methodology}

This study uses a quasi-experimental design with quantitative approaches to see the effect of cause-effect. The type of quasi experimental design used is the nonequivalent groups pre-post tests design. This quasi-experimental design was used in this study because random distribution cannot be done in the process of selecting the respondents (Chua, 2006; White \& Sabarwal, 2014). The researcher selected two teaching strategies of higher order thinking skills which are cooperative learning for the control group and using Nutri-Score for the treatment group. Pretest was administered before treatment while post-test was administered after treatment to both groups. The efficiency of treatments $\left(X_{1}\right.$ and $\left.X_{2}\right)$ in terms of higher order thinking skills is determined by studying the differences between the score mean of pre-test and post-test for both groups. Table 2 illustrates the design of quasi-experimental design implemented in this study.

Table 2 Study Design

\begin{tabular}{lll}
\hline Group & Design illustration \\
Treatment & Nutri-Score \\
Control & Cooperative learning & Exposure to the Nutri-Score \\
Guidance : & $=$ Exposure to the cooperative learning \\
$\mathrm{X}_{1}$ & $\rightarrow \mathrm{O}_{2}$ \\
$\mathrm{X}_{2}$ & First evaluation process which is pre-test \\
$\mathrm{O}_{1}$ & Second evaluation process which is post-test \\
$\mathrm{O}_{2}$ & $=$ Sequence of order
\end{tabular}

A total of 181 respondents from 2 secondary schools in Kedah and 2 secondary schools in Penang participated in this study. They are divided into treatment groups and control groups. Table 5.1 shows the number of respondents for each group according to the learning mode used. The control group studied the Nutrition cooperatively with the guidance of their teachers while the treatment group studied the Nutrition via Nutri-Score. Each of the selected schools contains two research groups which are one control group and one treatment group. Before the respondents joined the Nutrition Learning session, they answered the Entry Test which contained high cognitive level items for five topics before Nutrition. The purpose of the Entry Test is to find out the level of prior knowledge of the respondents in the form Biology subject as most of the 
INTERNATIONAL JOURNAL OF ACADEMIC RESEARCH IN BUSINESS AND SOCIAL SCIENCES

Vol. 8, No.2, February 2018, E-ISSN: 2222-6990 @ 2018 HRMARS

concepts in the previous five topics are being used in Nutrition. Table 3 shows the distribution of respondents by states and schools for both treatment and control groups.

Table 3 Distribution of respondents according to groups

\begin{tabular}{lllll}
\hline \multirow{2}{*}{ State } & \multirow{2}{*}{ School } & Group & & \multirow{2}{*}{ Total (N) } \\
\cline { 3 - 5 } Kedah & School A & 30 & 23 & \multirow{2}{*}{110} \\
& School B & 29 & 28 & \multirow{2}{*}{71} \\
\multirow{2}{*}{ Penang } & School C & 18 & 21 & 181 \\
& School D & 14 & 18 & 18 Treatment (N) \\
\hline
\end{tabular}

The pre-test questions and post-test questions are both different in content but similar in the cognitive level. Both the pre-test and post-test consist of a short item question and an essay question. The short item question tests the classifiying skills while the essay question tests the comparing and contrasting skill. All items in the pre-test and post-test were constructed by using the Rubrics for Specific Tasks or Situations (Marzano, Pickering \& McTighe, 2005) and were aligned with the level of Malaysian Certificate of Education examination. The difference is the additional of five diagrams of organisms to be classified in the short item question. For the essay question, the comparison between the human digestive system and the rabbit was changed to a comparison between the human and the cow digestive system. The purpose of modifying the items in the post-test is to prevent the respondents from giving their memorized answers from the pre-test.

\section{Results}

The Levene test in one-way ANOVA test was performed on the Entry Test score to test whether both treatment and control groups are equivalent in terms of their prior knowledge. The result of the analysis shown in Table 4 shows that the significant value for the Levene test exceed .05 . So there is no significant difference in the prior knowledge of the students from the treatment group and control group $(F(1,179)=0.107, p=.744)$. This confirms that the students in both groups are homogeneous in terms of their prior knowledge.

Table 4 Analysis of the Levene test for the score mean of the Entry Test across the groups

\begin{tabular}{lllll}
\hline Dependent variable & Levene statistic, $F$ & $d f 1$ & $d f 2$ & $p$ \\
\hline Entry Test & 0.107 & 1 & 179 & .744
\end{tabular}

Table 5 shows the descriptive statistics for three dependent variables from the treatment groups and control groups. The three dependent variables are the higher order thinking skills and its two components which are the classifying skill as well as the comparing and contrasting skill. It shows that the mean of the higher order thinking skills of the treatment group which is 36.46 is higher than the higher order thinking skills of the control group which is 26.21 by 10.25 . For the classifying skill, the treatment group mean of 57.00 also exceeds the control group mean of 42.69 by 14.31. Similarly, the mean of the comparing and contrasting skill of the treatment group which is 25.11 is higher than the mean of the comparing and contrasting skill of the control group which is 7.58 by 17.53 . 
INTERNATIONAL JOURNAL OF ACADEMIC RESEARCH IN BUSINESS AND SOCIAL SCIENCES

Vol. 8, No.2, February 2018, E-ISSN: 2222-6990 @ 2018 HRMARS

Table 5 Descriptive statistics for respondents from the treatment group and control group

\begin{tabular}{lllllll}
\hline \multirow{2}{*}{ Dependent variable } & \multicolumn{2}{c}{ Treatment group } & \multicolumn{3}{c}{ Control group } \\
\cline { 2 - 7 } & Mean & $\begin{array}{l}\text { Standard } \\
\text { deviation }\end{array}$ & $\mathrm{N}$ & Mean & $\begin{array}{l}\text { Standard } \\
\text { deviation }\end{array}$ & $\mathrm{N}$ \\
\hline Higher order thinking skills & 36.46 & 12.13 & & 26.21 & 11.37 & \\
Classifying skill & 57.00 & 18.48 & 90 & 42.69 & 21.48 & 91 \\
Comparing and contrasting skill & 25.11 & 18.19 & & 7.58 & 8.21 & \\
\hline
\end{tabular}

The Multivariate Analysis of Covariance (MANCOVA) test was used to analyze the data in this study by using the pre-test as a covariate. The result of the Multivariate Pillai's Trace test in Table 6 shows that there is a significant effect by the group $[F(4,175)=22.07, p<.05]$. In conclusion, the group is a factor that contributes to higher order thinking skills, classifying skill as well as the comparing and contrasting skill to the respondents. Next is the univariate test of Tests of Between-Subjects Effects, Estimated Marginal Means test and Bonferroni Adjusted Pairwise Comparison post hoc test.

Table 6 Result of Multivariate Pillai's Trace test

\begin{tabular}{llllll}
\hline Independent variable & Value & $F$ & $d f$ hypothesis & $d f$ error & $p$ \\
\hline Group & 0.34 & 22.07 & 4.00 & 175.00 & .00 \\
\hline
\end{tabular}

Table 7 shows the univariate test result of the Tests of Between-Subjects Effects. The result shows that there is a significant group effect on the dependent variable that is higher order thinking skills $[F(1,178)=26.72, p<.05]$. The $\mathrm{R}^{2}$ value shows that the independent variable which is the group contributes $30.6 \%$ change to the dependent variable that is higher order thinking skills. The result also shows that there is a significant group effect on the dependent variable of classifying skill $[F(1,178)=18.83, p<.05] . \mathrm{R}^{2}$ values indicate that the independent variables which is the group contributes $14.0 \%$ change to the dependent variable that is the classifying skill. Besides, there is a significant group effect on the dependent variable which is the comparing and contrasting skill $[F(1,178)=60.96, p<.05]$. The $\mathrm{R}^{2}$ value indicates that the independent variable that is the group contributes $35.6 \%$ change to the dependent variable that is the comparing and contrasting skill. 
INTERNATIONAL JOURNAL OF ACADEMIC RESEARCH IN BUSINESS AND SOCIAL SCIENCES

Vol. 8, No.2, February 2018, E-ISSN: 2222-6990 @ 2018 HRMARS

Table 7 Result of the Tests of Between-Subjects Effects

\begin{tabular}{|c|c|c|c|c|c|c|c|}
\hline $\begin{array}{l}\text { Dependent } \\
\text { variable }\end{array}$ & Source & $\begin{array}{l}\text { Total square } \\
\text { type III }\end{array}$ & $d f$ & $\begin{array}{l}\text { Mean } \\
\text { square }\end{array}$ & $F$ & $p$ & $R^{2}$ \\
\hline \multirow{2}{*}{$\begin{array}{l}\text { Higher order } \\
\text { thinking skills }\end{array}$} & Group & 3073.68 & 1 & 3073.68 & \multirow[t]{2}{*}{26.72} & \multirow[t]{2}{*}{.00} & \multirow[t]{2}{*}{.306} \\
\hline & Error & 20475.96 & 178 & 115.03 & & & \\
\hline \multirow{2}{*}{ Classifying skill } & Group & 7386.61 & 1 & 7386.61 & \multirow[t]{2}{*}{18.83} & \multirow[t]{2}{*}{0.00} & \multirow[t]{2}{*}{.140} \\
\hline & Error & 69816.55 & 178 & 392.23 & & & \\
\hline \multirow{2}{*}{$\begin{array}{l}\text { Comparing and } \\
\text { contrasting skill }\end{array}$} & Group & 10902.52 & 1 & 10902.52 & \multirow[t]{2}{*}{60.96} & \multirow[t]{2}{*}{0.00} & \multirow[t]{2}{*}{.356} \\
\hline & Error & 31836.145 & 178 & 178.86 & & & \\
\hline
\end{tabular}

The result of the Estimated Marginal Means test as in Table 8 shows that the higher order thinking skills for the respondents in the treatment group is better than for the respondents in the control group. This is because the adjusted mean for the treatment group which is 35.52 is higher than the adjusted mean for the control group which is 27.13 by 8.39 . The classifying skill for the respondents from the treatment group is also better than for the respondents from the control group. This is because the adjusted mean of the treatment group which is 56.35 is more than the adjusted mean for the control group which is 43.34 by 13.01 . The comparing and contrasting skill for the respondents in the treatment group is also better than for the respondents from the control group. This is because the adjusted mean for the treatment group which is 24.24 is higher than the adjusted mean for the control group which is 8.44 by 15.80 .

Table 8 Result of Estimated Marginal Means test

\begin{tabular}{llll}
\hline Dependent variable & Group & Adjusted mean & Standard error \\
\hline \multirow{2}{*}{ Higher order thinking skills } & Treatment & 35.52 & 1.14 \\
& Group & 27.13 & 1.14 \\
\hline \multirow{2}{*}{ Classifying skill } & Treatment & 56.35 & 2.11 \\
& Group & 43.34 & 2.10 \\
\hline \multirow{2}{*}{ Comparing and contrasting skill } & Treatment & 24.24 & 1.42 \\
& Group & 8.44 & 1.42 \\
\hline
\end{tabular}

Next, the Bonferroni Adjusted Pairwise Comparison post hoc test was performed to verify the group that causes the significant differences. The result of this test as shown in Table 9 confirms that the higher order thinking skills of the treatment group is better than the higher order thinking skills of the control group where the excess of the adjusted mean is 8.39. The difference is significant because $p<.05$. In conclusion, there is a significant difference in the achievement of the higher order thinking skills between the control and the treatment groups. At the same time, the higher order thinking skills for the treatment group is much better. 
The result of the test also confirms that the mean difference of the classifying skill for the treatment group is better compared to the classifying skill of the control group where the excess of the adjusted mean is 13.01 . The difference is significant because $p<.05$. In conclusion, there is a significant difference in the achievement of the classifying skill between control and treatment groups. At the same time, the classifying skill of the treatment group is much better.

The result of the test also confirms that the mean difference in the comparing and contrasting skill for the treatment group is better compared to the comparing and contrasting skill of the control group with the adjusted mean excess of 15.80. The difference is significant because $p<.05$. In conclusion there is a significant difference in the achievement of comparing and contrasting skill between the control and treatment groups. At the same time, the comparing and contrasting skill for the treatment group is much better.

Table 9 Result of Bonferroni Adjusted Pairwise Comparison Test

\begin{tabular}{llllll}
\hline Dependent variable & $\begin{array}{l}\text { Group } \\
(\mathrm{I})\end{array}$ & $\begin{array}{l}\text { Group } \\
(\mathrm{II})\end{array}$ & $\begin{array}{l}\text { Mean difference } \\
(\mathrm{I}-\mathrm{II})\end{array}$ & $\begin{array}{l}\text { Standard } \\
\text { error }\end{array}$ & $p$ \\
\hline $\begin{array}{l}\text { Higher order thinking } \\
\text { skills }\end{array}$ & Treatment & Control & 8.39 & 1.62 & .00 \\
& Control & Treatment & -8.39 & 1.62 & .00 \\
\hline \multirow{2}{*}{ Classifying skill } & Treatment & Control & 13.01 & 3.00 & .00 \\
& Control & Treatment & -13.01 & 3.00 & .00 \\
\hline \multirow{2}{*}{$\begin{array}{l}\text { Comparing and } \\
\text { contrasting skill }\end{array}$} & Treatment & Control & 15.80 & 2.02 & .00 \\
& Control & Treatment & -15.80 & 2.02 & .00 \\
\hline
\end{tabular}

\section{Discussion}

Nutri-Score is a courseware that integrates various types of multimedia technology into it to deliver the teaching of Nutrition. Nutri-Score is also interactive. The multimedia technology contained in the Nutri-Score is what gloriously enhances the higher order thinking skills of the respondents. The result of the study by Wenglinsky (1998) found to be parallel with this result in which higher order thinking skills of the respondents were enhanced after being taught by using multimedia technology. The study of using an interactive multimedia courseware to teach Biology to the students of class VIII by Satyaprakasha and Sunitha (2014) reinforces this finding as there was an increase in achievement score for the application skill of the respondents.

The multimedia technologies contained in the Nutri-Score are photos of images snapped by the researcher, real videos recorded by the researcher, animated videos of the movement of materials in the human digestive system, rabbit and cow and so as the animated pedagogical agent. In terms of videos, the researcher includes videos showing the real situations of mangrove ecosystem and paddy field ecosystem which are presented before teaching the classifying skill of organisms. These videos indirectly promote authentic learning as they expose the students to the real experiences. The animated pedagogical agent which was ejected in several teaching 
INTERNATIONAL JOURNAL OF ACADEMIC RESEARCH IN BUSINESS AND SOCIAL SCIENCES

Vol. 8, No.2, February 2018, E-ISSN: 2222-6990 C 2018 HRMARS

slides has succeeded in attracting the interest of the respondents and motivate them to finish learning Nutrition with the Nutri-Score.

\section{Conclusion}

The results of the data analysis showed that the achievement of the respondents from the treatment group exceeded the achievement of the respondents from the control group significantly from the aspect of higher order thinking skills and the two components of the higher order thinking skills which are the classifying skill as well as the comparing and contrasting skill. This result shows that multimedia coursewares which integrated with various technologies and appropriate models and theories such as in the Nutri-Score are suitable for enhancing the higher order thinking skills, especially in the classifying skill as well as the comparing and contrasting skill. Hence, the researcher suggests this study to be extended to the other topics in Biology and other Science subjects as well.

\section{Acknowledgement}

Thank you very much to:

1. The principles, Biology teachers and students who had involved in this research.

2. Ministry of Education Malaysia.

\section{Corresponding Authors}

1. Noraini Mohamed Noh, Faculty of Education and Human Development, Sultan Idris Education University, 35900 Perak, Malaysia.

Email: noraini.mn@fppm.upsi.edu.my

\section{References}

Barak, M., \& Shakhman, L. (2008). Fostering higher-order thinking in science class: Teachers' reflections. Teachers and Teaching: Theory and Practice, 14(3), 191-208. doi: 10.1080/13540600802006079

Chua, Y. P. (2006). Kaedah dan statistik penyelidikan: Kaedah penyelidikan (Buku 1). Shah Alam: McGraw-Hill Education (Malaysia) Sdn. Bhd.

Kim, C., \& Baylor, A. L. (2008). A virtual change agent: Motivating pre-service teachers in their future classrooms. Educational Technology and Society, 11(2), 309-321. Retrieved from https://www.researchgate.net/publication/220374597_A_Virtual_Change_Agent_Motiv ating_Pre-service_Teachers_to_Integrate_Technology_in_Their_Future_Classrooms

King, F. J., Goodson, L., \& Rohani, F. (2009). Higher order thinking skills. Center for Advancement of Learning and Assessment. Retrieved from http://www.cala.fsu.edu/files/higher _order_thinking_skills.pdf

Malaysian Examinations Syndicate. (2010). Kupasan Mutu Jawapan SPM 2010 Biologi 2 4551/2. Putrajaya.

Malaysian Examinations Syndicate. (2013). Kupasan Mutu Jawapan SPM 2013 Biologi 2 4551/2. Putrajaya.

Malaysian Examinations Syndicate. (2014). Kupasan Mutu Jawapan SPM 2014 Biologi 2 4551/2. Putrajaya. 
Marzano, R. J., Pickering, D., \& McTighe, J. (2005). Assessing student outcomes: Performance assessment using the dimensions of learning model. Alexandria, Virginia: Association for Supervision and Curriculum Development (ASCD).

MDEC (2008). Penilaian perisian-perisian kursus Kementerian Pelajaran Malaysia. Retrieved from http://www.mscmalaysia.my/sites/default/files/pdf/publications references/ Penilaian _Perisian_-_Perisian_Kursus.pdf.

Ministry of Education Malaysia. (2005). Integrated curriculum for secondary schools: Curriculum specifications Biology (Form 4). Putrajaya: Curriculum Development Centre.

Rajendran, N. S. (2010). Teaching and acquiring higher-order thinking skills: Theory and practise. Tanjong Malim: Sultan Idris Education University.

Satyaprakasha, C. V., \& Sunitha, B. (2014). Effectiveness of multimedia teaching on achievement of VIII standard students in Biology. International Journal of Informative \& Futuristic Research, 1(8). Retrieved from: http://www.ijifr.com/pdfsave/27-04-201442320-042014302Dr\%20CVS\%20ACH\%20a3a.pdf

Thomas, A., \& Thorne, G. (2009). How to increase higher level thinking. The Centre for Development and Learning. Retrieved from http://www.cdl.org/articles/how-toincrease-high-order-thinking/

Wenglinsky, H. (1998). Does it compute? The relationship between educational technology and student achievement in Mathematics. Educational Testing Service Policy Information Center. Retrieved from www.mff.org/pubs/ME161.pdf.

White, H., \& Sabarwal, S. (2014). Quasi-experimental design and methods. Florence, Italy: United Nations Children's Fund (UNICEF). Retrieved from https://www.unicefirc.org/publications/pdf/brief_8_quasi-experimental\%20design_eng.pdf. 